\title{
Studi Aspek Mikrobiologis Dan Kimiawi Minuman Jamu Gendong Kunyit Asam Di Jimbaran dan Kedonganan, Bali
}

\section{Study Of Microbiological And Chemical Aspects Of Tamarind Turmeric Sour Herbs In Jimbaran And Kedonganan, Bali}

\author{
Thanastasya Yolanda ${ }^{1}$, Luh Putu Trisna Darmayanti ${ }^{1 *}$, Agus Selamet Duniaji ${ }^{1}$
}

Program Studi Ilmu dan Teknologi Pangan, Fakultas Teknologi Pertanian, Universitas Udayana Kampus Bukit Jimbaran, Badung-Bali

*Penulis korespondensi: LP Trisna Darmayanti, Email: trisnadarmayanti@unud.ac.id

\begin{abstract}
"Jamu Gendong Kunyit Asam (Tamarind Turmeric Sour Herbs)" is a typical Indonesian drink that is quite famous which is one of the legacies of the Indonesian nation's ancestors who have medicinal properties in maintaining health and for healing a disease. This study aims to determine aspects of chemistry and microbiology as well as food safety of Tamarind Turmeric Sour Herbs in Jimbaran and Kedonganan, Bali by using survey method and research. The observed variabels include total microbial, coliforms, Escherichia coli, $\mathrm{pH}$, total acid, total vitamin $\mathrm{C}$. The results of microbiological aspect test in this study showed that two samples of Jamu Gendong Kunyit Asam (Tamarind Turmeric Sour Herbs) at Jimbaran and Kedonganan,Bali does not meet the requirements according to SNI 7388:2009 namely samples B and E with indigo in sample $\mathrm{B}$ that is $30 \times 10^{-1}$ and sample $\mathrm{E}$ which is $1 \times 10^{-1}$. The result of chemistry aspect are if the increase in total vitamin $\mathrm{C}$ will effect the increase in total acid and $\mathrm{pH}$ will be more acid. Besaide that, E. coli bacteria can grow at a $\mathrm{pH}$ of 5-7 and the compound content of the tamarind fruit is also antibacterial so that most of Jamu Gendong Kunyit Asam (Tamarind Turmeric Sour Herbs) at Jimbaran and Kedonganan are not contaminated with E.coli.
\end{abstract}

Keywords: Jamu Gendong, Tamarind Turmeric, Coliform, Escherichia coli

\section{PENDAHULUAN}

Jamu gendong merupakan minuman khas Indonesia yang cukup terkenal yang merupakan salah satu warisan leluhur Bangsa Indonesia. Biasanya jamu sering digunakan sebagai minuman tradisional yang mempunyai khasiat obat. Pemanfaatan jamu gendong sebagai pengobatan didasarkan pengalaman dari leluhur secara turun-temurun, yang digunakan untuk tindakan preventif dalam menjaga kesehatan dan untuk penyembuhan suatu penyakit (Pratiwi, 2005).
Menurut UU RI No. 7 Tahun 1996 Tentang Perlindungan Pangan (Pemerintah Republik Indonesia, 1996) Keamanan pangan didefinisikan sebagai kondisi dan upaya yang diperlukan untuk mencegah pangan dari kemungkinan cemaran biologis, kimia, dan benda lain yang dapat mengganggu, merugikan, dan membahayakan kesehatan manusia. Jamu gendong termasuk produk home industry, yang dalam pembuatannya masih sederhana dan rentan dengan isu keamanan pangan. Adanya cemaran E. coli pada jamu gendong dapat menurunkan kualitas serta 
menimbulkan masalah kesehatan bagi konsumen. Faktor yang mempengaruhi adanya cemaran E. coli sangat beragam di antaranya: penggunaan air, alat dan bahan yang digunakan, proses pembuatan, serta perajin jamu itu sendiri. Kesehatan dan kebersihan perajin jamu gendong juga perlu diperhatikan untuk mempertahankan kualitas dari jamu yang dihasilkan.

Keberadaan E. coli dalam bahan pangan dapat menimbulkan masalah kesehatan bagi masyarakat, karena keberadaannya merupakan suatu indikator sanitasi pengolahan pangan. Meskipun sebagian besar serotipe E. coli tidak berbahaya dan hidup bersimbiosis di dalam saluran pencernaan manusia dan hewan, tetapi ada beberapa serotipe yang memungkinkan memiliki sifat patogen dan terlibat secara langsung dalam timbulnya penyakit diare pada anak-anak serta penyakit serius lainnya.

Keamanan dan mutu minuman tradisional tergantung dari bahan baku, prosedur, dan pelaksanaan pembuatan, peralatan yang digunakan, sanitasi dan higiene, pengemasan termasuk bahan serta personalia yang terlibat dalam pembuatan minuman tradisional (Ditjen POM, 1994). Berdasarkan uraian diatas, maka diperlukan penelitian mengenai cemaran Koliform dan E. coli pada jamu gendong kunyit asam di Jimbaran dan Kedonganan, Bali.

\section{METODE PENELITIAN}

\section{Tempat dan Waktu}

Penelitian ini dilaksanakan di Laboratorium Mikrobiologi Pangan dan Laboratorium Analisis Pangan Fakultas Teknologi Pertanian, Gedung Agrokomplek, Universitas Udayana Jalan PB. Sudirman Denpasar. Waktu penelitian ini dilaksanakan selama dua bulan yakni dari bulan Agustus 2019 sampai Oktober 2019.

\section{Bahan dan Alat}

Bahan yang digunakan dalam penelitian ini adalah jamu gendong kunyit asam, Peptone Water (PW), Plate Count Agar (PCA), Lactose Broth (LB), Eosin Methylene Blue Agar (EMBA), Potato Dextrose Agar (PDA), alkohol, dan akuades, $\mathrm{H}_{2} \mathrm{SO}_{4}$, phenolphthalein (PP) $1 \%$, larutan

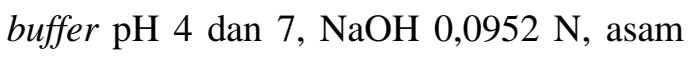
sulfat $0,6 \mathrm{M}$, natrium fosfat, amonium molybdate.

Alat yang digunakan dalam penelitian ini adalah botol kaca, cawan petri, tabung reaksi, tabung durham, inkubator, spektrofotometer, laminar air flow, $\mathrm{pH}$ meter, timbangan analitik, pipet mikro, erlenmeyer, bunsen, vortex, batang bengkok, kapas, alumunium foil, plastik tahan panas, pipet volume, labu ukur, sentrifugasi, tip $100 \mu \mathrm{L}$, dan tip $1000 \mu \mathrm{L}$.

\section{Rancangan Penelitian}

Penelitian ini dilakukan dengan metode survei dengan teknik pengambilan sampel yang digunakan adalah Sampling jenuh yaitu teknik penentuan sampel jika 
semua anggota populasi digunakan sebagai sampel. Teknik ini dilakukan jika jumlah populasi kecil atau kurang dari 30 (Sugiyono, 2001). Terdapat 5 sampel jamu gendong kunyit asam yang diambil di Jimbaran dan Kedonganan, Bali. Sampel A, B, dan C diambil di Jimbaran dan sampel D dan E diambil di Kedonganan. Data hasil penelitian disajikan secara deskriptif dan dipresentasikan dengan tabel dan gambar.

\section{Variabel yang Diamati}

Variabel yang diamati adalah $\mathrm{pH}$ (AOAC, 1995), Total Asam (Sudarmadji et al., 1996), Total Vitamin C (Vuong et al., 2014), Total Mikroba (Buckle, 1987), Koliform, dan Escherichia coli (Cappucino dan Sherman, 1992) sesuai SNI 7388:2009.

\section{Pelaksanaan Penelitian}

Pengambilan sampel diambil di daerah Jimbaran dan Kedonganan, Bali. Sampel diambil di daerah Jimbaran sebanyak 3 sampel dan di daerah Kedonganan sebanyak 2 sampel. Pengambilan sampel dilakukan pada pagi hari pukul 06.00 WITA. Sampel yang sudah diambil dimasukkan kedalam ice box yang sudah disterilkan dengan alkohol. Adapun cara kerjanya yaitu, sebanyak $150 \mathrm{ml}$ sampel diambil dari masing-masing produsen dan diberi label, lalu dimasukkan kedalam ice box dan dibawa ke laboratorium untuk dilakukan uji selanjutnya.

\section{Analisis Total Mikroba}

Analisis total mikroba yang mengacu pada (Buckle, 1987) dalam pegujian jamu gendong kunyit asam menggunakan metode Total Plate Count (TPC). Sampel diambil sebanyak $5 \mathrm{ml}$ dan dimasukkan kedalam wadah atau plastik steril, kemudian ditambahkan sebanyak $45 \mathrm{ml}$ larutan Peptone Water $(\mathrm{PW})$ sehingga diperoleh pengenceran $10^{-1}$. Disiapkan pengeceran $10^{-}$ ${ }^{2}, 10^{-3}$, dan $10^{-4}$ yang berisi $9 \mathrm{ml}$ PW. Diambil dengan pipet $1 \mathrm{ml}$ larutan homogenan dari tabung $10^{-1}$ lalu dipindahkan ke tabung PW $10^{-2}, 1 \mathrm{ml}$ PW $10^{-2}$ dipindahkan ke tabung PW $10^{-3}$, dan $1 \mathrm{ml} \mathrm{PW} 10^{-3}$ dipindahkan ke tabung PW $10^{-4}$. Pengujian total mikroba dilakukan dengan media sebar. Dilakukan penuang Media Plate Count Agar (PCA) sebanyak $15 \mathrm{ml}$ ke dalam cawan petri steril kemudian didinginkan. Selanjutnya diambil sebanyak $0,1 \mathrm{ml}$ larutan menggunakan pipet steril dari tabung pengenceran yang berisi PW $10^{-2}, 10^{-3}$, dan $10^{-4}$ lalu dipindahkan ke dalam cawan petri yang telah berisi media PCA di letakkan diatasnya. Sampel yang telah dipindahkan kedalam cawan petri yang berisi media PCA dilakukan secara dupplo. Setelah itu diratakan/disebar dengan menggunakan batang gelas bengkok, dan didiamkan selam 1 jam. Kemudian diinkubasi cawan - cawan tersebut dengan posisi terbalik dalam incubator selama \pm 24 jam dengan suhu $37^{\circ} \mathrm{C}$.

\section{Analisis Koliform dan Escherichia Coli}

\section{Uji Penduga}

Sampel jamu dianalisis dengan presumtive test menggunakan metode Most 
Probable Number (MPN) dalam pengujian untuk mendeteksi bakteri koliform yang mengacu pada (Cappucino dan Sherman, 1992). Pengujian uji penduga menggunakan tiga seri tabung dan tiga tingkat pengenceran.

Disiapkan 9 tabung reaksi steril untuk satu sampel dan diberikan label pada masing-masing tabung. Dimasukkan $9 \mathrm{ml}$ Lactose Broth (LB) dengan menggunakan pipet ke dalam tabung lalu dimasukkan $1 \mathrm{ml}$ sampel larutan sehingga diperoleh pengenceran $10^{-1}, 10^{-2}$ dan $10^{-3}$ dan dihomogenkan. Tabung diinkubasi selama 48 jam dengan suhu $35^{\circ} \mathrm{C}$. Hasil uji penduga dikatakan positif apabila terdapat gas pada tabung durham sebesar $>10 \%$.

\section{Uji Penegasan dan Uji Lengkap Escherichia Coli}

Dari tabung yang positif terdapat gas pada uji penduga lalu dipindahkan menggunakan jarum inokulasi kedalam media EMBA secara aseptik. Diinkubasi selama 24 jam pada suhu $37^{\circ}$ C. Uji dikatakan positif bila terdapat koloni hijau metalik. Selanjutnya dilakukan uji lengkap yaitu koloni yang berwrna pada uji lengap diinokulasikan kedalam LB dengan jarum inokulasi secara aseptik lalu diinkubasi selama 24 jam pada suhu $37^{\circ} \mathrm{C}$.

Penentuan jumlah bakteri E. coli dalam sampel secara kuantitatif menggunakan rumus perhitungan oleh Fardiaz (1992). Satuan yang digunakan untuk menyatakan hasil perhitungan jumlah bakteri dalam sampel berdasarkan rumus tersebut yaitu CFU (Colony Form Unit/mL).

\section{Analisis pH}

Sebelum digunakan $\mathrm{pH}$ meter dikalibrasi terlebih dahulu menggunakan larutan buffer $\mathrm{pH} 4$ dan $\mathrm{pH}$ 7. Setelah dikalibrasi, elektroda $\mathrm{pH}$ meter dimasukkan dalam jamu gendong kunyit asam.

\section{Analisis Total Asam}

Analisis total asam yang mengacu pada (Sudarmadji et al., 1996) dalam penelitian jamu gendong kunyit asam menggunakan metode titrasi. Sampel jamu gendong kunyit asam diambil sebanyak 10 $\mathrm{ml}$ dan dimasukkan ke dalam labu ukur 100 $\mathrm{ml}$, ditambahkan akuades sampai tanda tera dan disaring dengan kertas saring. Filtrat yang dihasilkan dipipet sebanyak $25 \mathrm{ml}$ dan dimasukkan ke dalam erlenmeyer $250 \mathrm{ml}$. Ditambahkan indikator PP 1\% sebanyak 2-3 tetes dan dititrasi dengan $\mathrm{NaOH} 0,1 \mathrm{~N}$ sampai berubah warna menjadi merah muda. Total asam ditentukan dengan menggunakan rumus berikut:

$$
\begin{aligned}
& \text { Total asam }= \\
& \frac{\mathrm{ml} \mathrm{NaOH} \times \mathrm{N} \mathrm{NaOH} \times \mathrm{BM} \times \mathrm{P}}{\text { gram bahan } \times 1000} \times 100 \%
\end{aligned}
$$

Keterangan :

$$
\begin{array}{ll}
\mathrm{BM} & =\text { Berat molekul asam laktat } \\
\mathrm{P} & =\text { faktor pengenceran }
\end{array}
$$

\section{Analisis Total Vitamin C}

Analisis total vitamin $\mathrm{C}$ yang mengacu pada (Voung et al., 2014) dalam pengujian jamu gendong kunyit asam menggunakan metode absorbasi. Pengujian dilakukan dengan pencampuran reagen 
pelarut yang dipersiapkan dengan

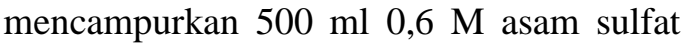
dengan 5.3218 gram natrium fosfat dan 2.471 gram ammonium molybdate. Sebanyak $3 \mathrm{ml}$ reagen dicampurkan dengan $0,3 \mathrm{ml}$ sample dan diinkubasi pada suhu $95^{\circ}$ C selama 90 menit dalam water bath. Setelah diinkubasi, sampel didinginkan dalam air dingin selama 5 menit sebelum diukur absorbannya dengan panjang gelombang $695 \mathrm{~nm}$. Hasil yang diperoleh kemudian disajikan dengan $\mathrm{mg}$ asam askorbat yang ekuivalen dengan mg/g AAE.

\section{HASIL DAN PEMBAHASAN}

\section{Total Mikroba}

Analisis total mikroba dengan menggunakan media Plate Count Agar (PCA) untuk minuman jamu gendong kunyit asam di Jimbaran dan Kedonganan, Bali dapat dilihat pada Tabel 1.

Tabel 1. Total mikroba jamu gendong kunyit asam di Jimbaran dan Kedonganan, Bali

\begin{tabular}{cccc}
\hline Sampel & Total Mikroba (koloni $/ g)$ & $\begin{array}{c}\text { Standard SNI } \\
7388: 2009\end{array}$ & Keterangan \\
\hline $\mathrm{A}$ & $1,08 \times 10^{5} \mathrm{koloni} / \mathrm{g}$ & & Memenuhi syarat \\
$\mathrm{B}$ & $1,34 \times 10^{5} \mathrm{koloni} / \mathrm{g}$ & & Memenuhi syarat \\
$\mathrm{C}$ & $8,05 \times 10^{4} \mathrm{koloni} / \mathrm{g}$ & $1 \times 10^{6} \mathrm{koloni} / \mathrm{g}$ & Memenuhi syarat \\
$\mathrm{D}$ & $2,11 \times 10^{5} \mathrm{koloni} / \mathrm{g}$ & & Memenuhi syarat \\
$\mathrm{E}$ & $8,26 \times 10^{4} \mathrm{koloni} / \mathrm{g}$ & & Memenuhi syarat \\
\hline
\end{tabular}

Berdasarkan hasil pengujian nilai rata-rata total mikroba pada minuman jamu gendong kunyit asam berkisar antara 1,08 x $10^{5} \mathrm{koloni} / \mathrm{g}$ sampai dengan $8,27 \times 10^{4}$ koloni/g (Tabel 1). Persyaratan maksimal total mikroba pada minuman tradisional sesuai SNI 7388:2009 adalah maksimal $1 \mathrm{x}$ $10^{6}$ koloni/g, keseluruhan sampel jamu gendong kunyit asam yang dijual di Jimbaran dan Kedonganan, Bali memenuhi persyaratan mutu minuman tradisional dengan nilai total mikroba yang tertinggi yaitu pada sampel D sebesar $2,40 \times 10^{5}$ koloni/g dan nilai total mikroba yang terendah yaitu pada sampel C sebesar $8,05 \mathrm{x}$
$10^{4}$ koloni/g. Hal ini disebabkan karena sebagian besar produsen jamu gendong sudah menerapkan cara pembuatan jamu dengan baik dimulai saat penyimpanan bahan baku jamu yang akan diproses pada nampan kering dan disimpan di tempat yang bersih dan jauh dari panas atau sinar matahari langsung. Kemudian pada saat proses pembuatan jamu selalu menggunakan alat-alat yang bersih dan kering untuk menjamin kebersihan jamunya. Sebelum proses pembuatan jamu, semua bahan-bahan yang digunakan dicuci dibawah air yang mengalir hingga bersih (Muhlisah, 2001). Pada proses pemasakan juga menggunakan 
air yang dimasak sampai mendidih karena pemanasan pada suhu tinggi dapat menyebabkan membran penyusun pada mikroorganisme menjadi lebih liquid sehingga sel mikroba dapat mengalami lisis (Paustian, 2007).

\section{Koliform dan Eschericia coli Uji Pendugaan Koliform}

Analisis uji pendugaan Koliform dengan media Lactose Broth (LB) selama 48 jam lalu dilanjutkan dengan Uji Pendugaan Escherichia coli pada minuman jamu gendong kunyit asam di Jimbaran dan Kedonganan, Bali dihitung dengan perhitungan tabel APM (Angka Paling Mungkin) yang menggunakan tiga seri tabung. Pengenceran seri dilakukan untuk mengurai kerapatan pertumbuhan koloni mikorba pada sampel yang akan diuji. Batas maksimum cemaran mikroba minuman tradisional sesuai SNI 7388:2009 untuk Koliform adalah $1 \times 10^{2} \mathrm{koloni} / \mathrm{g}$ dan APM Escherica coli $<3 / \mathrm{g}$.

Analisis pendugaan E. coli dengan menggunakan Lactose Broth yang berisi tabung durham didapatkan hasil data uji pendugaan dengan menggunakan perhitungan tabel APM (Angka Paling Mungkin) yang dapat dilihat pada Tabel 2.

Tabel 2. Hasil uji pendugaan koliform jamu gendong kunyit asam di Jimbaran dan Kedongan, Bali

\begin{tabular}{ccccc}
\hline Sampel & Seri A & Seri B & Seri C & $\begin{array}{c}\text { Uji Pendugaan Koliform APM } \\
\text { (koloni/ml) }\end{array}$ \\
\hline A & 0 & 0 & 0 & $<3,0$ \\
B & 0 & 2 & 3 & 16 \\
C & 0 & 0 & 0 & $<3,0$ \\
D & 0 & 1 & 0 & $<3,0$ \\
E & 2 & 2 & 0 & 21 \\
\hline
\end{tabular}

Kusuma (2009) menjelaskan proses fermentasi gula (laktosa) dalam media LB karena adanya bakteri koliform fekal yaitu Escherichia coli. Fermentasi gula dengan adanya energi yang dihasilkan bakteri akan menghasilkan asam piruvat dan asam asetat, kemudian muncul gelembung gas $\mathrm{Co}_{2}$ yang berada di dalam media. Namun uji pendugaan ini tidak dapat dijadikan acuan bahwa sampel yang terkontaminasi Koliform terdapat E. coli karena pada uji pendugaan memungkinkan berkembangnya mikroba jenis lain. Oleh karena itu sampel dilanjutkan dengan uji penegasan untuk 
menentukan apakah sampel tersebut terkontaminasi E. coli yang patogen.

\section{Uji Penegasan Escherichia coli}

Hasil uji pendugaan kemudian dilanjutkan ketahap uji penegasan yaitu dengan cara diambil $1 \mathrm{ml}$ sampel dari tabung reaksi yang terdapat gelembung didalamnya kemudian diinokulasikan ke dalam media yang berisi EMBA. Uji dikatakan positif jika terdapat warna hijau metalik. Hasil uji penegasan Escherihcia coli dapat dilihat pada Tabel 3.

Tabel 3. Hasil uji penegasan E. coli jamu gendong kunyit asam di Jimbaran dan Kedongan, Bali

Sampel Escherichia coli $\quad$ Standard SNI 7388:2009 Keterangan

\begin{tabular}{cccc}
\hline $\mathrm{A}$ & 0 & $<3 / \mathrm{g}$ & \\
$\mathrm{B}$ & $30 \times 10^{-1}$ & $<3 / \mathrm{g}$ & Tidak Memenuhi Syarat \\
$\mathrm{C}$ & 0 & $<3 / \mathrm{g}$ & Memenuhat \\
$\mathrm{D}$ & 0 & $<3 / \mathrm{g}$ & Memenarat \\
$\mathrm{E}$ & $1 \times 10^{-1}$ & $<3 / \mathrm{g}$ & Memenuhi Syarat \\
\hline
\end{tabular}

Hasil uji penegasan dari lima sampel jamu gendong kunyit asam menunjukkan bahwa dua diantaranya postif terkontaminasi E. coli yaitu sampel B dan E tidak memenuhi standar batas cemaran mikroba pada SNI 7388:2009 yaitu $1 \times 10^{2}$ koloni/g. Faktorfaktor yang dapat mendukung adanya kontaminasi E. coli pada produk jamu gendong yaitu kebersihan, baik dari segi kebersihan bahan baku dan peralatan yang digunakan maupun kebersihan perajin jamu dalam proses pembuatan dan penyajian jamu. Peralatan dan bahan baku lebih baik dicuci di air yang mengalir hingga bersih (Suharmiati, 2003). Namun apabila bahan baku yang digunakan memiliki kualitas buruk misalnya busuk ataupun berjamur lebih baik tidak digunakan dan dipisahkan dari bahan baku yang masih segar untuk menghindari adanya kontaminasi bakteri $E$. coli (Huda, 2015).

Kontaminasi bakteri Koliform dan $E$. coli juga berasal dari air yang digunakan. Hal ini dapat dicegah dengan cara merebus air terlebih dahulu sebelum digunakan. Faktor penyebab lainnya yaitu perilaku perajin/penjual produk jamu gendong dalam menyajikan untuk konsumen juga dapat menunjang terjadinya kontaminasi E. coli. Sebagian besar penjual jamu gendong ketika membuka tutup botol untuk menuangkan jamu, segera menutupnya kembali dan tidak membiarkan botol terbuka terlalu lama untuk menghindari kontaminasi melalui udara. Akan tetapi ada beberapa perajin/penjual yang tidak langsung menutup botol. Selain itu, ada juga penjual jamu gendong menyajikan jamunya dalam gelas kaca yang biasanya hanya dibilas 
dengan air sumur atau air PDAM yang dibawa dalam wadah terbuka tanpa ada pencucian dengan sabun.
Hasil pengukuran $\mathrm{pH}$ jamu gendong kunyit asam di Jimbaran dan Kedonganan, Bali dapat dilihat pada Gambar 1.

\section{Derajat Keasaman (pH)}

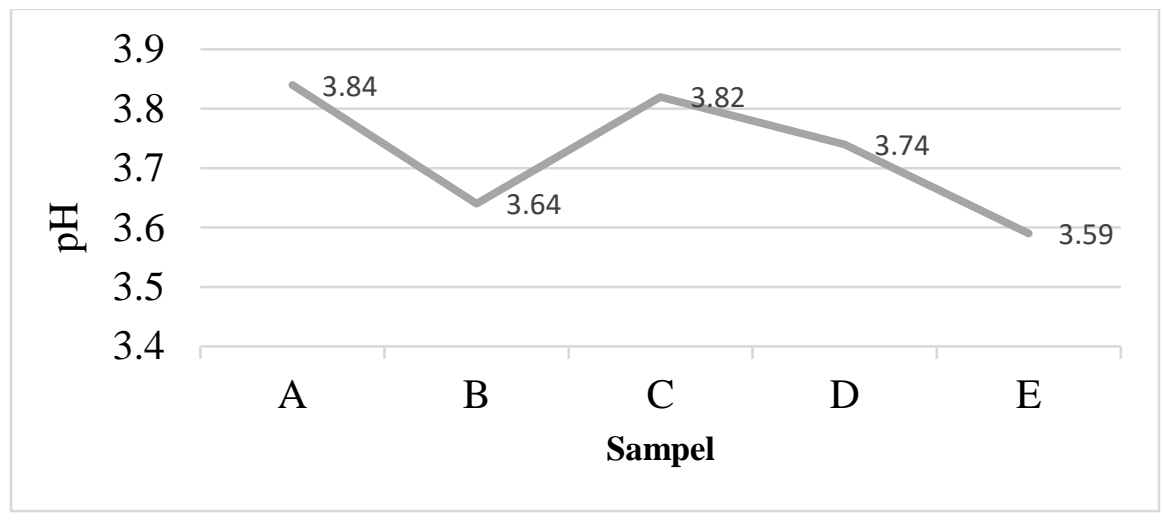

Gambar 1. Hasil uji pH minuman jamu gendong kunyit asam di Jimbaran dan Kedonganan, Bali

Hasil pengukuran $\mathrm{pH}$ jamu gendong kunyit asam dengan menggunakan $\mathrm{pH}$ indicator universal diperolah rata-rata nilai $\mathrm{pH}$ 3-4. Hasil pengukuran $\mathrm{pH}$ pada ekstrak buah asam dengan air panas yaitu 2,91 dan air dingin yaitu 2,00 (Nwodo, 2011). Data penelitian tersebut sesuai dengan data yang diperoleh dari seluruh penjuam jamu gendong kunyit asam yang dalam pembuatannya merebus buah asam terlebih dahulu sebelum dicampurkan dengan sari kunyit, sehingga didapatkan $\mathrm{pH} 3$ pada minuman jamu gendong kunyit asam. Perbedaan $\mathrm{pH}$ mempengaruhi tingkat ketahanan hidup bakteri E. coli. Kandungan asam organik pada buah asam selain berperan sebagai antibakteri juga menciptakan asam pada kunyit asam sehinggan $\mathrm{pH}$ yang dihasilkan lebih rendah. Oleh karena itu, hasil pengujian E. coli pada sampel jamu kunyit asam sebagian besar negatif.

\section{Total Asam}

Hasil uji total asam pada minuman jamu gendong kunyit asam di Jimbaran dan Kedonganan, Bali dapat dilihat pada Gambar 2. 


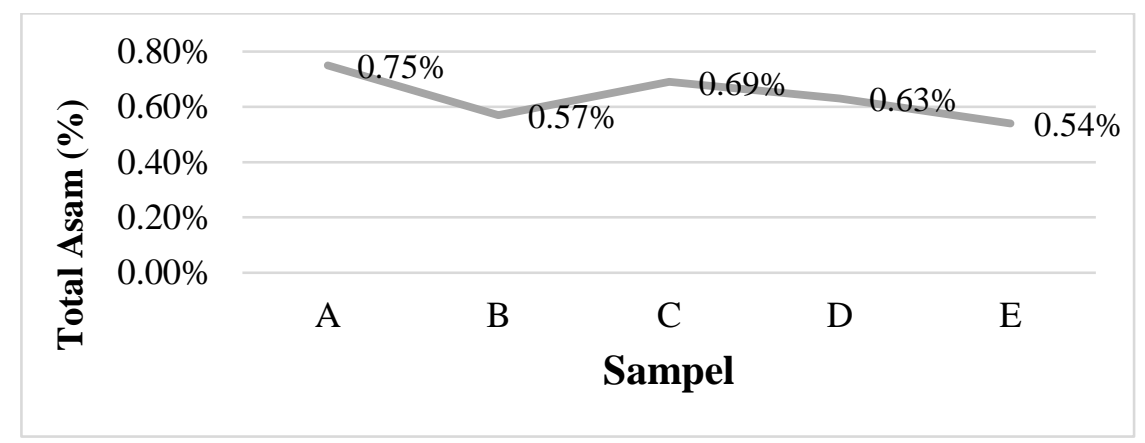

\section{Gambar 2. Hasil uji total asam minuman jamu gendong kunyit asam di Jimbaran dan kedongaan, Bali}

Asam yang digunakan untuk menguji total asam yaitu asam tartarat. Hasil pengujian total asam dapat dilihat pada Gambar 2 bahwa hasil yang didapatkan tidak berbanding terbalik terhadap $\mathrm{pH}$, yaitu pada sampel A sebesar 0,75\%, sampel B 0,57\%, sampel C 0,69\%, sampel D 0,63\% dan sampel E $0,54 \%$. Total asam sangat erat kaitannya dengan nilai $\mathrm{pH}$, dimana kenaikan total asam menunjukkan penurunan $\mathrm{pH}$ (Prasetyo, 2013). Selain itu, peningkatan asam pada bahan pangan juga dapat terjadi karena adanya penguraian glukosa menjadi asam (Tjahjadi, 2008).

Peningkatan nilai total asam dapat terjadi juga karena adanya peningkatan proporsi penggunaan kunyit dan asam jawa. Kunyit memiliki asam dengan nilai pH 6.50. penambahan kunyit yang ditambahkan pada saat pembuatan jamu kunyit asam akan membuat nilai total asam meningkat karena pada saat proses pengeringan, asam yang terdapat didalam bahan pembuatan jamu kunyit asam mengalami penguapan.

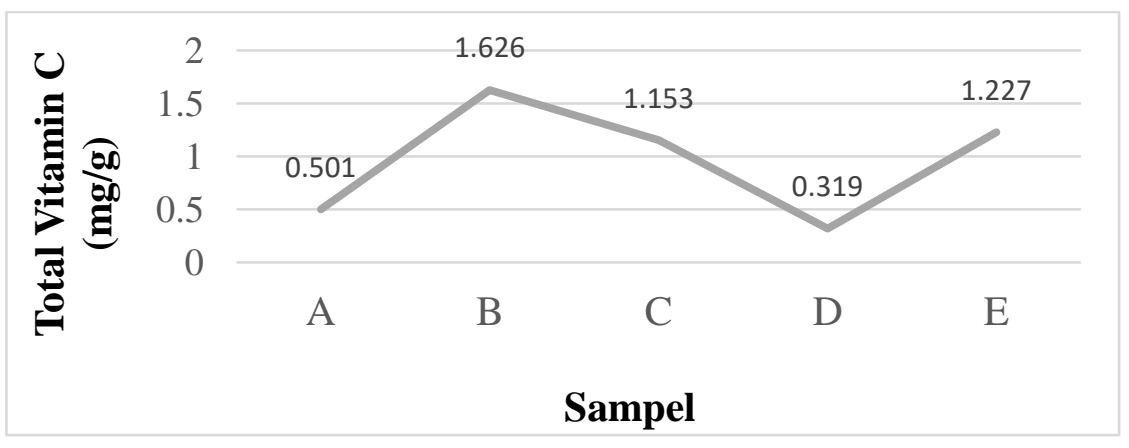

\section{Gambar 3. Hasil uji total vitamin C minuman jamu gendong kunyit asam di Jimbaran dan Kedonganan, Bali}

\section{Total Vitamin C}

Berdasarkan hasil pengujian vitamin $\mathrm{C}$ pada minuman jamu gendong kunyit asam, didapatkan nilai total vitamin $\mathrm{C}$ yang tertinggi yaitu pada sampel B sebesar 1,626 $\mathrm{mg} / \mathrm{g}$ dan nilai vitamin $\mathrm{C}$ yang terendah yaitu 
pada sampel D sebesar $0,319 \mathrm{mg} / \mathrm{g}$. Hasil dari uji vitamin $\mathrm{C}$ juga berpengaruh dengan $\mathrm{pH}$. Apabila $\mathrm{pH}$ semakin rendah makan nilai vitamin $\mathrm{C}$ semakin stabil, hal tersebut terjadi karena adanya pengaruh dari jenis bahan yang digunakan beberapa pedagang. Adapun beberapa pedagang yang menambahkan jeruk nipis pada saat pembuatan jamu, sedangkan beberapa pedagang yang lainnya tidak menambahkan jeruk nipis pada saat pembuatan jamu gendong kunyit asam. Selain itu, pengaruh hasil dari vitamin $\mathrm{C}$ disebabkan karena penambahan air dan pemanasan. Pemanasan yang semakin lama akan menyebabkan vitamin $\mathrm{C}$ mengalami kerusakan karena vitamin $\mathrm{C}$ bersifat larut dalam air, mudah teroksidasi dan tidak tahan panas (Herper et al., 1986).

\section{KESIMPULAN \\ DAN SARAN}

\section{Kesimpulan}

Secara mikrobiologis terdapat dua sampel jamu kunyit asam yang tercemar E. coli yaitu pada sampel $\mathrm{B}$ dan $\mathrm{E}$ dengan nilai pada sampel B sebesar $30 \times 10^{-1}$ dan sampel E sebesar $1 \times 10^{-1}$. Terdapatnya cemaran $E$. coli pada sampel B dan E dapat disebabkan karena bahan yang digunakan, peralatan yang digunakan, cara pembuatan dan proses penyajian jamu tersebut. Secara kimiawi pada sampel jamu kunyit asam yaitu jika kenaikan total vitamin $\mathrm{C}$ maka akan berpengaruh dengan kenaikan total asam dan pH semakin asam. Biasanya, bakteri E. coli dapat tumbuh pada $\mathrm{pH}$ 5-7 dan kandungan senyawa kimia pada buah asam juga memiliki kemampuan sebagai antibakteri sehingga didapatkan tiga sampel jamu kunyit asam yang tidak tercemar E.coli.

Sampel jamu gendong kunyit asam yang dijual di Jimbaran dan Kedonganan, Bali terdapat dua sampel yang dalam penelitian ditemukan adanya cemaran E. coli yaitu pada sampel B dan E sehingga tidak aman dikonsumsi karena tidak memenuhi persyaratan SNI 7388:2009.

\section{Saran}

Perlu dilakukannya sosialisai kepada para produsen jamu mengenai cara pengolahan dan proses pembuatan jamu dengan benar sehingga didapatkan minuman tradisional yang aman bila dikonsumsi oleh konsumen.

\section{DAFTAR PUSTAKA}

BSN. 2009. Batas Maksimum Cemaran Mikroba Dalam Pangan. Standar Nasional Indonesia (SNI) SNI 7388:2009. Dewan Standarisasi Indonesia, Jakarta.

Buckle, K.A., R.A. Edwards, G.H. Fleet, dan M. Wootton. 1987. Ilmu Pangan. Jakarta : UI-Press.

Cappuccino, JG. dan N. Sherman. 1992. Microbiology: A Laboratory Manual. The Benjamin/Cummings Publishing Company,Inc. Clifornia.

Direktorat Jendral POM. 1994. Petunjuk Pelaksanaan Cara Pembuatan Obat Tradisional Yang Baik (CPOTB). Departemen Kesehatan Republik Indonesia, Jakarta.

Harper, L.J., B.J. Deaton dan J.A Driskel. 1986. Pangan, Gizi dan Pertanian 
(Suhardjo, penerjemah). UI Press. Jakarta.

Huda, M. 2015. Faktor-faktor yang berhubungan dengan jumlah bakteri pada jamu beras kencur yang dijual di pasar tradisional Kota Bandar Lampung. J Analis Kesehatan, 2(4): 436-445.

Muhlisah, F. 2001. Temu-temuan dan Emponemponan. Kanisius. Yogyakarta. 234 hal.

Nwodo, U.U., Obiiyeke, G.E., Chigor, V.N., Okoh, A.I., 2011. Assessment of Tamarindus indica Extracts for Antibacterial Activity. Int. J. Mol. Sci. volume: 6385-6396.

Paustian, T. 2007. Microbiology and Bacteriology. Jakarta: Universitas Indonesia.

Prasetyo, E. 2013. Data Mining Konsep Dan Aplikasi Menggunakan Matlab. Yogjakarta: Penerbit Andi.

Pratiwi, S. T. 2005. Pengujian Cemaran Bakteri dan Cemaran Kapang/Khamir Pada Produk Jamu Gendong di Daerah Istimewa Yogyakarta.

Sudarmadji. S., Haryono, B., Suhardi. 1996. Analisa Bahan Makanan dan Pertanian. Liberty Yogyakarta. Yogyakarta.

Sugiyono. 2001. Metode Penelitian. CV Alfa Beta, Bandung.

Suharmiati. 2003. Menguak Tabir dan Potensi Jamu Gendong. Jakarta: Penerbit Agromedia Pustaka, Halaman 2-4, 33-35.

Tjahjadi, C. 2008. Pengantar Teknologi Pangan. Universitas Padjadjaran. Jatinangor.

Vuong, Q.V., S. Hirun, T. L. K. Chuen, C. D. Goldsmith, M. C. Bowyer, A. C. Chalmers,P. A. Phillips, dan C. J. Scarlett. 2014. Physicochemical Composition, Antioxidant Andantiproliferative Capacity of a Lilly Pilly (Syzygium paniculatum) Extract. J. Herb. Med. 4, 134-140. 